University of Nebraska - Lincoln

DigitalCommons@University of Nebraska - Lincoln

1981

\title{
Effect of Level of Dietary Calcium-Phosphorus During Growth and Gestation on Calcium-Phosphorus Balance and Reproductive Performance of First-Litter Sows
}

\author{
R. D. Nimmo \\ Allied Mills \\ E. R. Peo, Jr. \\ University of Nebraska-Lincoln \\ J. D. Crenshaw \\ University of Nebraska-Lincoln \\ B. D. Moser \\ University of Nebraska-Lincoln
}

A. J. Lewis

University of Nebraska-Lincoln, alewis2@unl.edu

Follow this and additional works at: https://digitalcommons.unl.edu/animalscifacpub

Part of the Animal Sciences Commons

Nimmo, R. D.; Peo, Jr., E. R.; Crenshaw, J. D.; Moser, B. D.; and Lewis, A. J., "Effect of Level of Dietary Calcium-Phosphorus During Growth and Gestation on Calcium-Phosphorus Balance and Reproductive Performance of First-Litter Sows" (1981). Faculty Papers and Publications in Animal Science. 657. https://digitalcommons.unl.edu/animalscifacpub/657

This Article is brought to you for free and open access by the Animal Science Department at DigitalCommons@University of Nebraska - Lincoln. It has been accepted for inclusion in Faculty Papers and Publications in Animal Science by an authorized administrator of DigitalCommons@University of Nebraska - Lincoln. 


\title{
EFFECT OF LEVEL OF DIETARY CALCIUM - PHOSPHORUS DURING GROWTH AND GESTATION ON CALCIUM - PHOSPHORUS BALANCE AND REPRODUCTIVE PERFORMANCE OF FIRST - LITTER SOWS ${ }^{1}$
}

\author{
R. D. Nimmo ${ }^{2}$, E. R. Peo, Jr., J. D. Crenshaw, B. D. Moser and A. J. Lewis \\ University of Nebraska ${ }^{3}$, Lincoln 68583
}

\begin{abstract}
Summary
Twenty-four bred gilts were used in a $\mathrm{Ca}-\mathrm{P}$ metabolism trial. Twelve gilts were fed gestation treatment A (13 g Ca, $10 \mathrm{~g} / \mathrm{day})$, while the other 12 were fed gestation treatment B (19.5 g Ca, $15 \mathrm{~g} \mathrm{P} /$ day $)$. One-half of the gilts in each treatment group were fed $.65 \% \mathrm{Ca}, .50 \% \mathrm{P}$ from 7 to $94 \mathrm{~kg}$, and half were fed $.975 \% \mathrm{Ca}, .75 \% \mathrm{P}$ for the same period. Treatment $B$ gilts excreted more $(P<.005)$ fecal and urinary $P$. Twenty-four first litter sows fed the same treatment diets during growth and gestation and given .75\% $\mathrm{Ca}, .50 \% \mathrm{P}$ during lactation were used in a $\mathrm{Ca}$ and $\mathrm{P}$ balance trial conducted from day 38 to 42 of lactation. No differences in fecal, urinary or milk $\mathrm{Ca}$ or $\mathrm{P}$ were noted between sows fed the different diets during growth or gestation. A higher $(\mathrm{P}<.05)$ value for $\mathrm{Ca}$ balance during lactation was observed for sows fed treatment diet B during gestation than for those fed gestation diet $\mathrm{A}$. There were growth treatment $\times$ gestation treatment interactions $(\mathrm{P}<.05)$ for both $\mathrm{Ca}$ and $\mathrm{P}$ balance. No differences were noted in total pigs farrowed, total pigs farrowed alive, average weaning weight or number of pigs weaned. Birth weights were higher $(\mathrm{P}<.05)$ for pigs from sows fed diet $B$ during gestation than for pigs from sows fed diet $A$. Pre- and postfarrowing weights, weaned sow weight and lactation gain were similar regardless of treatment fed during growth or gestation.
\end{abstract}

\footnotetext{
${ }^{1}$ Published as Paper No. 6081, Journal Ser., Nebraska Agr. Exp. Sta.

${ }^{2}$ Present address: Allied Mills, Libertyville, IL 60048.

${ }^{3}$ Dept. of Anim. Sci. Acknowledgment is made to Alice Teter for assistance with the preparation of this manuscript and to Mary Barnes, Cecilia Stodd and Tom Crenshaw for laboratory and statistical counsel.
}

(Key Words: Sow, Gilt, Calcium, Phosphorus, Gestation, Lactation.)

\section{Introduction}

The $\mathrm{Ca}$ and $\mathrm{P}$ requirements of gestating gilts are based on limited research. The NRC (1968, 1973) suggested requirements for gestating gilts were $15 \mathrm{~g} \mathrm{Ca}$ and $10 \mathrm{~g} \mathrm{P} /$ day, but redefined the requirements in 1979 (NRC, 1979) to $13.5 \mathrm{~g} \mathrm{Ca}$ and $10.8 \mathrm{~g} \mathrm{P} /$ day. Harmon et al. (1974) reported that gilts fed diets containing $.31 \% \mathrm{P}(5.58 \mathrm{~g} / \mathrm{day})$ during gestation farrowed normally and showed no consistent effects during lactation that could be attributed to $P$ feeding level during gestation. Still, the authors noted a high incidence of posterior paralysis among sows fed $.31 \% \mathrm{P}$ and suckled for 8 weeks. Harmon et al. (1975) also reported that sows fed a gestation $P$ level of $.33 \%$ with various $P$ levels during lactation produced litters of similar size and weight to those produced by sows fed $.68 \% \mathrm{P}$ during gestation. Nimmo et al. (1981) reported lower bone peak force values and less bone strength per unit area for gilts that had been fed $.65 \%$ $\mathrm{Ca}$ and $.50 \% \mathrm{P}$. They also found that $30 \%$ of the gilts on the lower $\mathrm{Ca}-\mathrm{P}$ treatments had to be removed from the trial because they were unable to stand, whereas the removal rate for the gilts given $.975 \% \mathrm{Ca}, .75 \% \mathrm{P}$ was negligible. Kornegay et al. (1973) reported similar farrowing and weaning performance and tissue parameters for sows fed either $10.3 \mathrm{~g} \mathrm{Ca}$ and $11.0 \mathrm{~g} \mathrm{P}$ or $15.5 \mathrm{~g} \mathrm{Ca}$ and $15.0 \mathrm{~g}$ $P$ daily for five reproductive cycles. The data presently available are inconsistent and inconclusive for a wide variety of response criteria that must be considered in the estimation of $\mathrm{Ca}-\mathrm{P}$ requirements of gilts during gestation.

This study was conducted to determine the effects of various levels of dietary $\mathrm{Ca}$ and $\mathrm{P}$ fed to gilts during growth and gestation on 
$\mathrm{Ca}-\mathrm{P}$ balance in the dam during gestation and lactation.

\section{Experimental Procedure}

Phase 1. Twenty-four gilts, all bred within a $\mathbf{5}$ - day period, were used in a $\mathrm{Ca}-\mathrm{P}$ metabolism trial conducted during gestation. Twelve of the gilts were fed $.65 \% \mathrm{Ca}$ and $.50 \% \mathrm{P}$ (growth treatment A) from 7.25 to $92.8 \mathrm{~kg}$, while the other 12 were fed $.975 \% \mathrm{Ca}$ and $.75 \% \mathrm{P}$ (growth treatment B). At $92.8 \mathrm{~kg}$, one-half of the gilts on growth treatment $A$ were assigned to gestation treatment A (13.0 g $\mathrm{Ca}$ and $10.0 \mathrm{~g} \mathrm{P} /$ day) and half were assigned to gestation treatment $\mathrm{B}(19.5 \mathrm{~g} \mathrm{Ca}$ and $15.0 \mathrm{~g}$ $P /$ day). The same assignment of gestation treatments was carried out for the 12 gilts on growth treatment B, creating four outcome growth-gestation treatment groups (six gilts/ group): growth $\mathrm{A}$-gestation $\mathrm{A}$, growth $\mathrm{A}$ gestation B, growth B-gestation A and growth B - gestation B. A detailed description of diets, feeding procedures, housing and breeding procedures has been given by Nimmo et al. (1981). Gilts were placed in metabolism crates at an average of 38 days of gestation and continued on their respective gestation diets for 3 days before the initiation of the collection period. All urine and feces were collected for 96 hours. Gilts had been catheterized with either 18-or 20-gauge 5 -cc foley catheters for urine collection. Urine was collected in 22-liter plastic containers, with volume determined daily, and diluted to the nearest $500 \mathrm{ml}$ volume with redeionized distilled water. After dilution, $5 \%$ of the sample was kept for analysis. Feces were collected at least three times daily, frozen and pooled over the 4-day period. Analysis of urine and feces for $\mathrm{Ca}$ and $\mathrm{P}$ was performed by an automated procedure adapted from Kessler and Wolfman (1964).

Pbase 2 Twenty-four lactating first-litter sows were used in a $\mathrm{Ca}-\mathrm{P}$ balance trial. All sows were offered $4.53 \mathrm{~kg}$ of a lactation diet containing $.75 \% \quad \mathrm{Ca}$ and $.50 \% \mathrm{P}$ daily (for complete description, see Nimmo et al., 1981). Sows and their litters were placed in metabolism crates at an average of 35 days postpartum and allowed to adjust for 3 days before collections were begun. During the adjustment and collection periods, litters were separated from their dams because the dams were catheterized, but the piglets were allowed to suckle three times at $4-\mathrm{hr}$ intervals and twice at 6-hr intervals each day. Collection and analysis of feces and urine were carried out as in phase 1. Milk production, measured as litter weight gain over a 24-period, was determined on the fourth day of collection; the litters were weighed before and immediately after each suckling and the gains summed. Milk samples were collected 1 day thereafter for subsequent Ca-P analysis by the procedure of Kessler and Wolfman (1964). Since endogenous losses of $\mathrm{Ca}$ and $\mathrm{P}$ were not determined, all retention and balance data are "apparent" values.

All gilts were weighed at 109 days of gestation, immediately after farrowing, and at weaning. Data were collected on 67 litters from the four outcome growth-gestation treatment groups (A-A, A - B, B - A, B - B).

Analysis of treatments was carried out to evaluate responses during the growth and gestation periods on gestation and lactation Ca-P balance. Groups growth A-gestation-A and growth A-gestation-B (A-A, A-B) were pooled to create pooled growth group $A$ (p-grow A) while groups B-A and B-B were pooled to create growth group B. Similar procedures were followed to create $p$-gest $A$ and $p$-gest $B(A-A, B-A=p$-gest $A ; A-B$, $B-B=p$-gest $B$ ). Comparisons of $p$-grow $A$ versus $\mathrm{p}$-grow $\mathrm{B}$ and $\mathrm{p}$-gest $\mathrm{A}$ versus $\mathrm{p}$-gest $B$ were made in both phrases. The growth $X$ gestation interaction was also tested. Statistical analysis was conducted by least-squares procedures designed and implemented by Barr et al. (1976) and Steel and Torrie (1960).

\section{Results and Discussion}

In phase 1 , no differences $(P>.05)$ between pooled growth groups were found in $\mathrm{Ca}$ or $\mathrm{P}$ losses from the feces or urine or in the amount of $\mathrm{Ca}$ or $\mathrm{P}$ retained (table 1). However, gilts fed p-gest $\mathrm{A}(13.0 \mathrm{~g} \mathrm{Ca}$ and $10.0 \mathrm{~g} \mathrm{P} /$ day $)$ excreted less fecal $\mathrm{Ca}$ daily than gilts fed p-gest $\mathrm{B}$ (19.5 $\mathrm{Ca}$ and $15.0 \mathrm{~g} \mathrm{P} /$ day); 12.2 vs $16.2 \mathrm{~g}$ ). Only a small amount of urinary Ca was excreted daily by the gilts and there were no differences due to treatment. More $\mathrm{Ca}$ was retained daily by gilts fed $\mathrm{p}$-gest $\mathrm{B}$ diets $(P<.005)$ than by those fed $p$-gest $A$ $(3.15$ vs $.68 \mathrm{~g})$. Gestating gilts fed $13.5 \mathrm{~g}$ $\mathrm{Ca} /$ day excreted $91.1 \%$ of their intake, or $12.3 \mathrm{~g}$, while gilts fed $19.5 \mathrm{~g} \mathrm{Ca} /$ day excreted only $83.8 \%$ of their intake, or 16.3 grams. The net increase in Ca retained for gilts fed $19.5 \mathrm{~g}$ 


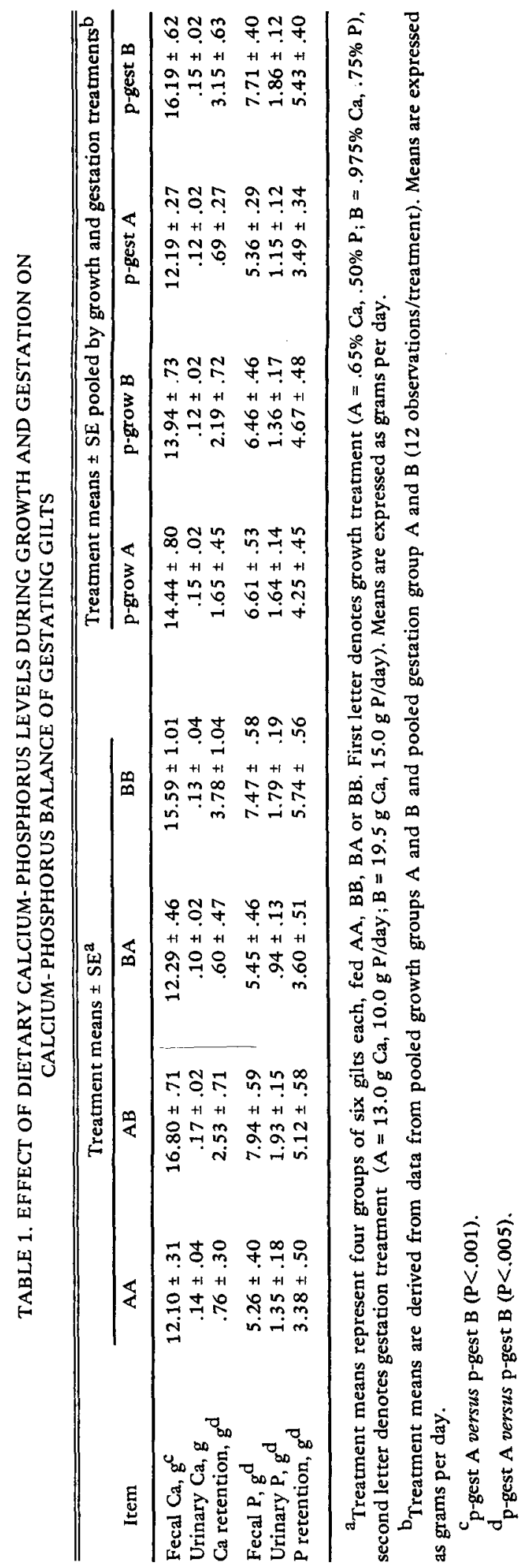

$\mathrm{Ca} /$ day was 2.47 grams. More fecal and urinary $\mathrm{P}$ was excreted $(\mathrm{P}<.005)$ by gilts fed $\mathrm{p}$-gest $B$ than by those fed $p$-gest $A$. More $P$ was retained $(\mathrm{P}<.005)$ by gilts fed $\mathrm{p}$-gest $\mathrm{B}$. Although $5 \mathrm{~g}$ more $\mathrm{P}(10.0$ vs $15.0 \mathrm{~g})$ was fed to the $\mathrm{p}$-gest $\mathrm{B}$ gilts, they retained only 1.94 $\mathrm{g}$ more.

The results of the gestation metabolism trial indicate that more $\mathrm{Ca}$ and $\mathrm{P}$ were retained when $19.5 \mathrm{~g} \mathrm{Ca}$ and $15.0 \mathrm{~g} \mathrm{P} /$ day were fed than when $13.5 \mathrm{~g} \mathrm{Ca}$ and $10.0 \mathrm{~g} \mathrm{P} /$ day were fed. The latter levels are similar to the NRC (1979)-suggested requirements for gestating gilts and sows. This suggests that the NRCsuggested levels might be too low if greater retention of $\mathrm{Ca}$ and $\mathrm{P}$ during gestation is important. Although the data reflect a 4-day period at approximately 40 to 45 days of gestation, an appreciable net increase in $\mathrm{Ca}$ and $P$ retained probably existed throughout gestation for the gilts fed $19.5 \mathrm{~g} \mathrm{Ca}$ and $15.0 \mathrm{~g}$ $\mathrm{P} /$ day.

Bone data obtained on these gilts following one lactation (Nimmo et al., 1981) suggested that because the bones were stronger per unit area, they were more dense. This supports the hypothesis that more resorption of $\mathrm{Ca}$ and $\mathbf{P}$ from the skeleton had occurred during lactation in gilts fed p-gest $A$ so that the animals could meet lactation $\mathrm{Ca}$ and $\mathrm{P}$ demands.

No differences $(P>.05)$ in fecal, urinary or milk $\mathrm{Ca}$ and $\mathrm{P}$ were observed between $\mathrm{p}$-grow and $\mathrm{p}$-gest groups (table 2). In addition, no differences were noted between p-grow $A$ and $p$-grow $B$ or between $p$-gest $A$ and $p$-gest $B$ in retention, balance or intake of $\mathrm{Ca}$ or $\mathrm{P}$. A higher $(\mathrm{P}<.05)$ value for $\mathrm{Ca}$ balance during lactation was observed for gilts fed p-gest $B$ than for those fed p-gest A (14.45 vs 11.99). In addition, there was a p-grow $x$-gest interaction $(P<.05)$ for both $\mathrm{Ca}$ and $\mathrm{P}$ balance. Some trends concerning $\mathrm{Ca}$ and $\mathrm{P}$ balance may be more evident when the means for the outcome growthgestation groups (table 2) are evaluated (A-A, $\mathrm{A}-\mathrm{B}, \mathrm{B}-\mathrm{A}, \mathrm{B}-\mathrm{B})$. Although $\mathrm{Ca}$ and $\mathrm{P}$ intake was the same for all lactating sows (.75\% $\mathrm{Ca}$ and $.50 \% \mathrm{P}$ ), some variation existed because of different rates of feed consumption. There was also variation in milk volume and grams of $\mathrm{Ca}$ and $\mathrm{P}$ excreted in the milk daily, although no differences existed within pooled growth and pooled gestation treatment groups. Milk volume may have been affected by the periodic 


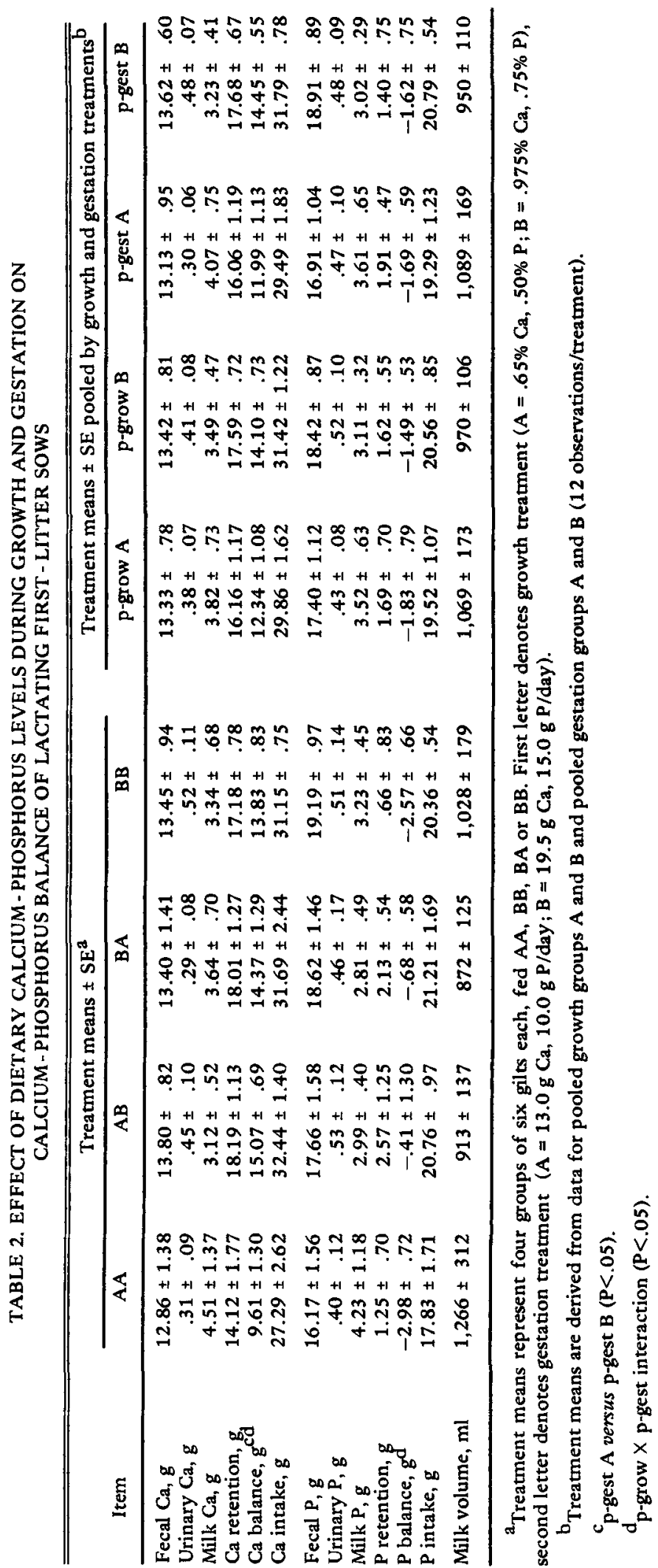




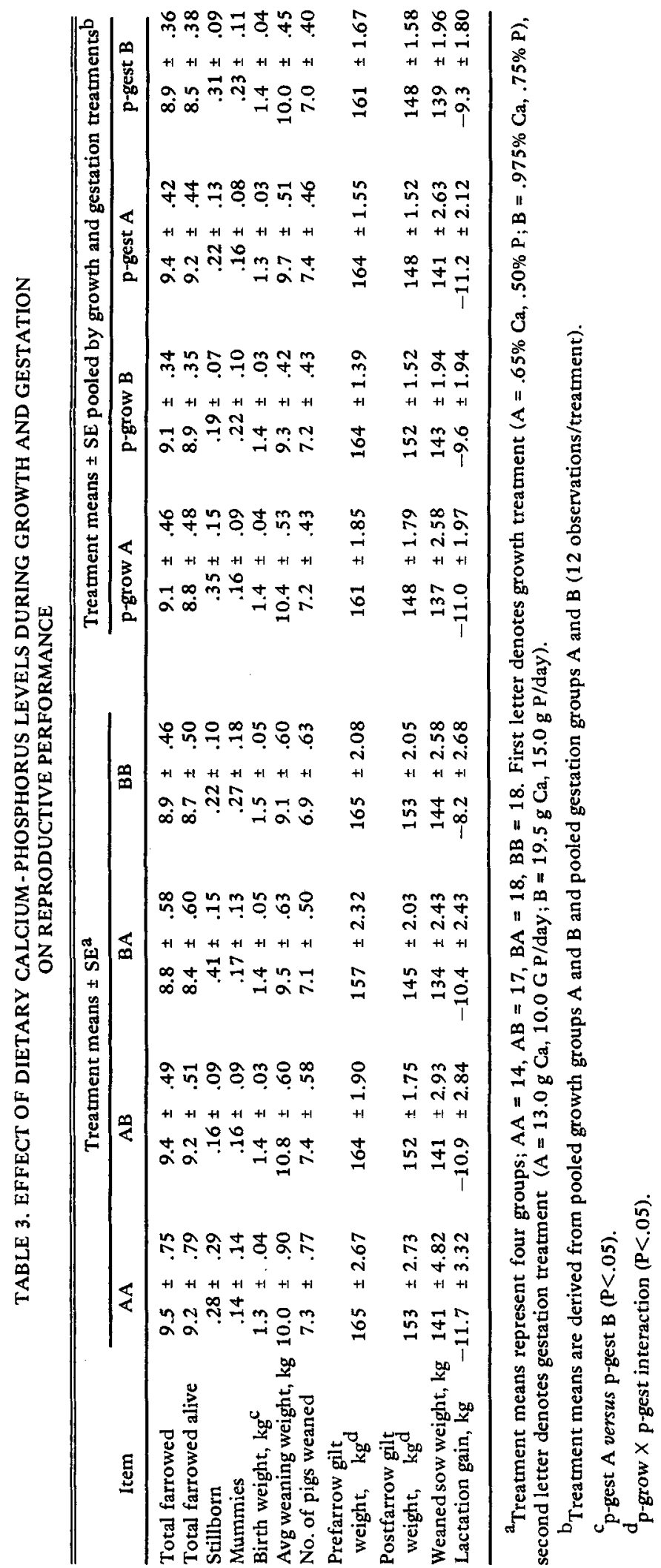


suckling procedure used for piglets, although milk volumes did represent a total $24-\mathrm{hr}$ collection rather than estimates, as have been reported by other workers (Wells et al., 1940; Lodge, 1959; Mahan et al., 1971).

Since the $\mathrm{Ca}$ and $\mathrm{P}$ levels $(.75 \% \mathrm{Ca}$ and $.50 \%$ P) were the same for all sows during lactation, a wider range of $\mathrm{Ca}-\mathrm{P}$ levels during gestation may have resulted in detectable treatment differences in $\mathrm{Ca}$ and $\mathrm{P}$ balance during lactation, although all outcome treatment groups (A-A, A-B, B-A, B-B) were in negative $\mathrm{P}$ balance. These results are in contrast with those reported by Harmon et al. (1975), who indicated that all but one group of sows fed 5.94 or $13.24 \mathrm{~g}$ of $\mathrm{P}$ during gestation and $13.5,16.5$ or $19.5 \mathrm{~g} \mathrm{P}$ during a 28 -day lactation period remained in positive $\mathrm{P}$ balance.

A summary of reproductive performance is presented in table 3 . No differences $(P>.05)$ were noted in total pigs farrowed, total pigs farrowed alive, stillborn pigs, mummies, average weaning weight or number of pigs weaned. Harmon et al. (1975) reported no difference in litter size and litter weight among first-litter sows fed a corn-soybean meal diet with or without supplemental $\mathrm{P}$ during gestation. Harmon et al. (1975) reported that sows fed $.65 \% \mathrm{P}$ during lactation weaned lighter pigs than sows fed $.45 \% \mathrm{P}$, although the numbers of pigs weaned were similar. Birth weights were greater $(P<.05)$ for pigs from sows given $\mathrm{p}$-gest $\mathrm{B}$ during gestation than for those from sows on p-gest A (1.4 vs $1.3 \mathrm{~kg})$. Kornegay et al. (1973) reported no differences in farrowing or weaning performance traits, except average weaning weight, between pigs from sows fed low Ca-P levels $(10.3 \mathrm{~g} \mathrm{Ca}$ and $11.0 \mathrm{~g}$ $\mathrm{P})$ and pigs from sows fed high levels $(15.5 \mathrm{~g}$ $\mathrm{Ca}$ and $15.0 \mathrm{~g} \mathrm{P}$ ). In this trial, weaning weight was higher for pigs from sows fed the lower $\mathrm{Ca}$ and $\mathrm{P}$ levels. The standard errors for all pig response criteria were large because of the normal variation found in litter data. Regardless, any trends that may have occurred were difficult to interpret because of the magnitude of the standard error for treatment means. Pre - and postfarrowing gilt weights, weaned sow weights and lactation gains were similar for the p-grow and p-gest treatment groups. Also, although a p-grow $\times$-gest interaction $(\mathrm{P}<.05)$ was observed for preand postfarrowing gilt weights, the average lactation weight loss was $1.02 \mathrm{~kg}$ for the 42 day lactation period. Kornegay et al. (1973) reported an $11.4 \mathrm{~kg}$ weight loss during five reproductive cycles of 42 days each, while Harmon et al. (1975) noted a $17-\mathrm{kg}$ weight loss over a 28-day lactation. Dietary Ca-P treatment during gestation and subsequent lactation appears to have little if any effect on sow weight loss during lactation.

The results of the studies of $\mathrm{Ca}$ and $\mathrm{P}$ balance during gestation and lactation, in conjunction with data on bone characteristics and the number of gilts failing to complete gestation because of their inability to stand (Nimmo et al., 1981), do not agree with the level of $\mathrm{P}$ reported by Harmon et al. (1975) as satisfactory for first-litter gestating gilts. One of the levels of dietary $\mathrm{Ca}$ and $\mathrm{P}$ utilized for gestating gilts in this study $(13.5 \mathrm{~g} \mathrm{Ca}$ and $10.0 \mathrm{~g} \mathrm{P} /$ day) was similar to the NRC (1979). suggested requirements $(13.5 \mathrm{~g} \mathrm{Ca}$ and $10.8 \mathrm{~g}$ $\mathrm{P} /$ day). When consideration is given to maximal skeletal development and the ability of gestating gilts to withstand the rigors of being reared in confinement, the data indicate that $13.5 \mathrm{~g} \mathrm{Ca}$ and $10.0 \mathrm{~g} \mathrm{P} /$ day was not adequate while $19.5 \mathrm{~g} \mathrm{Ca}$ and $15 \mathrm{~g} \mathrm{P}$ appeared quite adequate for gestating gilts. Thus, the results reported herein do not support the 1979 NRC requirements for $\mathrm{Ca}$ and $\mathrm{P}$ for gestating gilts.

\section{Literature Cited}

Barr, A. J., J. H. Goodnight, J. P. Sall and J. T. Helwig. 1976. A User's Guide to SAS. SAS Institute Inc., Raleigh, NC.

Harmon, B. G., C. Liu, S. Cornelius, J. Pettigrew, D. H. Baker and A. H. Jensen. 1974. Efficacy of different phosphorus supplements for sows during gestation and lactation. J. Anim. Sci. 39:1117.

Harmon, B. G., C. Liu, A. Jenson and D. H. Baker. 1975. Phosphorus requirement of sows during gestation and lactation. J. Anim. Sci. 40:660.

Kessler, G. and M. Wolfman. 1964. An automated procedure for the simultaneous determination of calcium and phosphorus. Clin. Chem. 10:686.

Kornegay, E. T., H. Thomas and T. Meacham. 1973. Evaluation of dietary calcium and phosphorus for reproducing sows housed in total confinement on concrete or in dirt lots. J. Anim. Sci. $37: 493$.

Lodge, G. A. 1959. The energy requirements of lactating sows and the influence of the level of food intake upon milk production and reproductive performance. J. Agr. Sci. (Camb.) $53: 177$.

Mahan, D. C., D. E. Becker, H. W. Norton and A. H. Jenson. 1971. Milk production in lactating sows and time lengths used in evaluating milk production estimates. J. Anim. Sci. 33:35. 
Nimmo, R. D., E. R. Peo, Jr., B. D. Moser and A. J. Lewis. 1981. Effect of level of dietary calciumphosphorus during growth and gestation on performance, blood and bone parameters of swine. J. Anim. Sci. 52:1330.

NRC. 1968. Nutrient Requirements of Domestic Animals, No. 2. Nutrient Requirements of Swine. National Academy of Sciences - National Research Council, Washington, DC.

NRC. 1973. Nutrient Requirements of Domestic Animals, No. 2. Nutrient Requirements of Swine. National Academy of Sciences - National
Research Council, Washington, DC.

NRC. 1979. Nutrient Requirements of Domestic Animals, No. 2. Nutritional Requirements of Swine. National Academy of Sciences - National Research Council, Washington, DC.

Steel, R. G. D. and J. H. Torrie. 1960. Principles and Procedures of Statistics. McGraw-Hill Book Co., New York

Wells, W., W. M. Beeson and D. E. Brady. 1940. Frequency of nursing and number of pigs influences milk production in the sow. Res. Bull. Idaho Agr. Exp. Sta. No. 236. 